\title{
Tożsamość kulturowa współczesnych potomków górali beskidzkich osiadłych w Serbii
}

\section{The cultural identity of descendants of the Beskidy Mountains highlanders settled in Serbia}

\begin{abstract}
Katarzyna Marcol, Toutowie. Język i pamięć w ustanawianiu wspólnoty Wiślan w Banacie, Wydawnictwo Uniwersytetu Śląskiego, Katowice 2020.
\end{abstract}

DOI: 10.12775/LL.4.2021.007 | CC BY-ND 4.o

Publikacja Katarzyny Marcol to owoc jej terenowych prac badawczych prowadzonych w Serbii w latach 2008-2019. Auorka odkryła tam zupełnie nową przestrzeń do przeprowadzenia badań antropologicznych, w efekcie czego powstała wyjątkowo ciekawa monografia na temat potomków migrantów z Wisły, beskidzkich górali, którzy już od lat 20. XIX w. docierali do Banatu na południowych rubieżach Cesarstwa Austro-Węgierskiego w poszukiwaniu pracy i lepszego życia. Osiedlali się tam wśród zróżnicowanej etnicznie i wyznaniowo społeczności lokalnej, która odtąd nazywała ich Toutami (węgierskie określenie 
Słowaków), tak samo zresztą Wiślanie określali później sami siebie. Wynika to - zdaniem autorki - z faktu, że w owym czasie górale ze Śląska Cieszyńskiego nie postrzegali swojej tożsamości w kategoriach narodowych. Co więcej, przynależność do struktur słowackiego kościoła ewangelickiego zadecydowała o ich identyfikowaniu się $\mathrm{z}$ narodem słowackim.

Przeprowadzona przez autorkę precyzyjna analiza relacji między poszczególnymi etnicznymi mniejszościami umożliwiła jej scharakteryzowanie przemian zachodzących w pamięci zbiorowej Wiślan, dla których głównym elementem samoidentyfikacji stała się religia ewangelicka. Proces kształtowania się tożsamości Toutów został przeanalizowany przez Katarzynę Marcol w sposób wyjątkowo pogłębiony, co umożliwiło jej wyeksponowanie wpływu skomplikowanego kontekstu kulturowego i politycznego na postępujące przeobrażenia tożsamościowe potomków emigrantów z oddalonego Śląska Cieszyńskiego, który przez lata był im zupełnie nieznany (zapomniany). Odnowienie relacji z Polską, a przede wszystkim ze społecznością wiślańską, nastąpiło dopiero na przełomie XX i XXI w. w wyniku aktywności kapłanów ewangelicko-augsburskich, a także polskich instytucji samorządowych oraz Ambasady RP w Belgradzie.

Dzięki wieloletniej obserwacji uczestniczącej autorka zgromadziła bogatą dokumentację związaną z kształtowaniem się poczucia tożsamości Toutów, która rozwijała się nie w izolacji, ale w interakcji z innymi mniejszościami etnicznymi. Szczególnie ważną rolę odegrał w tym procesie bezpośredni (rodzinny) przekaz kulturowy, wykorzystujący co prawda obraz świata zachowany w XIX-wiecznej gwarze wiślańskiej i religii luterańskiej, ale z drugiej strony stopniowo zmierzający do akceptowania (oswajania) relacji z sąsiadującymi społecznościami reprezentującymi inne mniejszości etniczne.

Wyjątkowo interesująca i inspirująca do naukowych refleksji jest przeprowadzona przez Marcol analiza gwary wiślańskiej funkcjonującej wśród potomków migrantów mieszkających w Serbii we wsi Ostojićevo. Język ten autorka określa jako „domowy” (używa się go bowiem współcześnie już tylko w trakcie spotkań rodzinnych i nieoficjalnych), a jego analize wzbogaca wieloma cytatami z przeprowadzonych przez siebie wywiadów. Dostrzega też znaczące podobieństwo funkcjonowania gwary Toutów z procesami zachodzącymi w gwarze wiślańskiej na Zaolziu. $\mathrm{W}$ obu przypadkach mamy bowiem do czynienia z peryferyjnym charakterem gwar, odseparowaniem ich od wpływów dominującego języka polskiego, co przesądziło o zachowaniu się w nich wielu archaizmów. Jednak postępująca integracja zróżnicowanej etnicznie społeczności Banatu prowadzi do stopniowego zanikania gwary jako języka „domowego”; na jej miejsce wchodzi język serbski, obowiązujący w szkołach. Z kolei język słowacki, używany w praktykach religijnych i liturgii kościelnej, jest silnie powiązany z obrzędowością rodzinną i doroczną Toutów.

W monografii obszernie omówione zostały przemiany zachodzące w obrzędowości weselnej, wynikające m.in. z narastającej liczby małżeństw etnicznie mieszanych, co nasila postępujący proces asymilacji kulturowej potomków wspólnoty wiślańskiej z innymi grupami etnicznymi. Jest to bez wątpienia 
pozytywny efekt życia w środowisku wieloetnicznym i wielowyznaniowym, który prowadzi do przenikania się zróżnicowanych elementów kulturowych, zresztą nie tylko w sferze obrzędowości. Jak pisze Marcol, „[p]roces zapożyczeń i transmisji przebiega tu między językami ze sobą spokrewnionymi, a tam, gdzie nie ma barier językowych lub są one niewielkie, dochodzi do wielu zapożyczeń, zwłaszcza w folklorze” (s. 153). Autorka wykazuje zarazem, że depopulacja Toutów prowadzi do zaniku tradycji wiślańskiej na rzecz elementów pochodzenia obcego, których źródeł można szukać nawet w kulturze węgierskiej. Tym samym tradycyjna „obrzędowość weselna przodków przestała mieć znaczenie jako wyróżnik własnej tożsamości etnicznej” (s.159).

Ma to oczywiście znaczący wpływ na przemiany pamięci zbiorowej. To odrębne, bardzo ciekawe zagadnienie, które autorka monografii z powodzeniem przeanalizowała, by na podstawie zgromadzonych materiałów prześledzić proces kształtowania się pamięci kulturowej Toutów. Zgromadzone w trakcie badań narracje wspomnieniowe potomków migrantów z Wisły, najczęściej przekazywane w gwarze wiślańskiej, ale również zapisywane, współtworzyły pamięć komunikatywną, która z czasem w trakcie przekazu międzypokoleniowego ulegała folkloryzacji i fabularyzacji. Doprowadziło to w efekcie do funkcjonowania w obiegu lokalnym narracji prezentujących świadomość tożsamościową wspólnoty, niekoniecznie powiązaną z losami konkretnej rodziny, ale kreującą obraz wspólnotowego świata. Wynikiem tych procesów było powstanie, rzec by można, swoistej mitologii Toutów, eksponującej istotne dla nich wydarzenia. Są to opowieści uznane przez Marcol za sagi rodzinne, które „mówią nam wiele na temat współczesnych strategii legitymizujących obecność Wiślan w Banacie oraz ukazują sposoby konstruowania granic służących budowaniu własnej tożsamości w środowisku zróżnicowanym etnicznie” (s. 198). Narracje te koncentrują się przede wszystkim wokół przyczyny opuszczenia Wisły przez przodków, ich wielotygodniowej pieszej wędrówki do Banatu, stopniowego „wtapiania się” kolejnych pokoleń w nową przestrzeń i to na tyle skutecznego, że Toutowie nie skorzystali z możliwości przesiedlenia się do Polski po II wojnie światowej. Ważną rolę integracyjną w powstaniu ich wspólnoty odegrała też wiara ewangelicka wyznaczająca miejsce pamięci i kultu w krajobrazie Ostojićeva, a zwłaszcza zachowane księgi metrykalne, które „pełnią już funkcję reliktów przeszłości - są one prezentowane gościom przybywającym z Polski jako świadectwa pochodzenia i emblematy przynależności zbiorowej” (s. 220).

Przemiany kulturowe i polityczne, a ponadto nasilenie się w ostatnich latach kontaktów z Polską, wyraźnie przyspieszyły proces zmian w pamięci zbiorowej Toutów i wyzwoliły potrzebe przedefiniowania tożsamości lokalnej w tożsamość narodową, zwłaszcza wśród najmłodszego pokolenia. Wpływ na to miały oczywiście również przekazy medialne. Jednak język polski nie jest, zdaniem Katarzyny Marcol, środkiem porozumiewania się potomków Wiślan żyjących w Serbii, jest on głównie „emblematem polskości w relacjach z innymi grupami etnicznymi”. Autorka nie jest też w stanie określić, w jakim kierunku będą przebiegały dalsze zmiany. Zastępowanie gwary wiślańskiej językiem serbskim 
przesądza o stopniowym zanikaniu opowieści przodków, jednak trudno powiedzieć, czy reinterpretacja tożsamości kulturowej Toutów będzie oznaczała rezygnację z tej nazwy własnej i zastąpienie jej pojęciem Polaka albo konkurencyjnego z nim Słowaka. Bez wątpienia ważne są tu oficjalne kontakty z Toutami jako „mniejszością polską”, zainicjowane w 2007 r. przez samorząd w Wiśle i Parafię Ewangelicko-Augsburską przy wsparciu Ambasady RP w Belgradzie, w ramach których eksponowana jest właśnie kategoria polskości, ukształtowana przez współczesne publiczne dyskursy polityczne. Mimo owego nacisku na „polskość”, jak pisze w zakończeniu swej monografii Katarzyna Marcol, „[n]ie jest wcale pewne, czy proces »unarodowienia« pamięci zatrzyma asymilację na tyle skutecznie, że kolejne pokolenia będą mogły bez zastanowienia mówić o sobie: my som Pol’ocy. Bo to, że nie będą o sobie mówili: my som Tołtowie, jest prawie pewne. [...] Może się zdarzyć, że dominacja serbskiej grupy większościowej będzie na tyle znacząca, że wyznaczniki tożsamości etnicznej zanikną wraz z odchodzącymi generacjami, polska tożsamość narodowa przestanie być wystarczająco atrakcyjna, aby się z nią identyfikować. [...] Dziś trudno wyrokować, jakie będą konsekwencje przechodzenia od tożsamości lokalno-etnicznej do tożsamości narodowej polskiej lub serbskiej” (s. 298-299).

Takie podsumowanie, zamykające obszerną monografię poświęconą potomkom migrantów z Wisły, nie tylko podkreśla wagę badań prowadzonych przez autorkę w nieznanej dotąd szerzej społeczności, ale ujawnia jednocześnie wszechstronność zaprezentowanych analiz, wskazując że tożsamość kulturowa grupy etnicznej jest kształtowana przez dwa istotne elementy: język i pamięć. Problematyka ta bez wątpienia jest ważna i nie zawsze dostrzegana we współczesnym świecie. 